\title{
Identity of care in a Psychosocial Care Center for Children and Adolescents who uses drugs*
}

\author{
IDENTIDADE DO CUIDADO EM CENTRO DE ATENÇÃO PSICOSSOCIAL \\ INFANTOJUVENIL PARA USUÁRIOS DE DROGAS
}

\section{IDENTIDAD DE LAATENCIÓN EN CENTROS DE ATENCIÓN PSICOSOCIAL PARA NIÑOS Y JÓVENES QUE CONSUMÍAN DROGAS}

\author{
Isabella Teixeira Bastos ${ }^{1}$, Vicente Sarubbi Jr. ${ }^{2}$, Tatiane Guimaraes Pedroso de Oliveira ${ }^{3}$, Patricia \\ Santos de Souza Delfini ${ }^{4}$, Camila Junqueira Muylaert ${ }^{5}$, Alberto Olavo Advincula Reis ${ }^{6}$
}

\begin{abstract}
Objective: To associate the territory of identity with the production of care within a PCC focusing on children and adolescents with drug abuse and their institutional identity. Method: We used the " process tracing methodology" in four research categories: focus groups, characterization of professionals, observing the everyday and interviewing two members of emblematic cases of the service. Results: The territory of identity of the institution, which operates the production of care is crossed by the difficulty of dealing with the complexity brought by the users and the performance of the PCC network. This paper is also permeated by different conceptions of care and small problematization of these issues in collective spaces of service. Conclusion: the discussion in focus groups and other devices can be powerful resources to reframe the meaning of care and identity of collective service.
\end{abstract}

\section{DESCRIPTORS}

Identity

Patient Care Management

Mental Health Services

\section{RESUMO}

Objetivo: relacionar o território da identidade com a produção de cuidado no interior de um CAPS voltado para crianças e adolescentes com uso abusivo de drogas e a sua identidade institucional. Método: Utilizou-se o "método do caso traçador" em quatro planos de investigação: grupos focais e caracterização dos profissionais, observação do cotidiano e entrevista com dois usuários de casos emblemáticos do serviço. Resultados: 0 território de identidade da instituição, do qual se opera a produção de cuidado, é atravessado pela dificuldade de lidar com a complexidade trazida pelos usuários e pela atuação do CAPS em rede. 0 trabalho é permeado também por diferentes concepções sobre cuidado e tímida problematização destas questões nos espaços coletivos do serviço. Conclusão: a discussão nos grupos focais e outros dispositivos podem ser potentes recursos para ressignificar o sentido do cuidado e da identidade do serviço no coletivo.

\section{DESCRITORES}

Identidade

Administração dos Cuidados ao Paciente Serviços de Saúde Mental

\section{RESUMEN}

Objetivo: Relacionar el territorio de la identidad con la producción de la atención dentro de un CAPS que enfrentan los niños $y$ adolescentes con el abuso de sustancias y su identidad institucional. Método: Se utilizó el "caso método trazador" en cuatro planes de investigación: grupos focales y de caracterización de los profesionales, la observación de lo cotidiano y la entrevista con dos miembros de los casos emblemáticos del servicio. Resultados: El territorio de identidad de la institución, que opera la producción de cuidados, es atravesado por la dificultad de hacer frente a la complejidad traída por los usuarios y el rendimiento de la red de CAPS. EI trabajo también está permeado por diferentes concepciones de la atención y el cuestionamiento tímido de estos temas en los espacios colectivos de servicio. Conclusión: la discusión en los grupos focales y otros dispositivos pueden ser recursos de gran alcance para replantear el significado del cuidado y la identidad de servicio en el colectivo.

\section{DESCRIPTORES}

Idendidad

Manejo de Atención al Paciente

Servicios de Salud Mental

\footnotetext{
Study extracted from the masters' dissertation entitled "Work processes in the construction of care: emblematic cases seen in a Psychosocial Care Center for Alcohol and Drugs for Children and Adolescents (PCC CAi)" presented at the School of Public Health, University of Sao Paulo, in the year 2013 financed by the National Council for Scientific and Technological Development - CNPq. ${ }^{1}$ Department of Maternal and Child Health, School of Public Health, University of Sao Paulo, Sao Paulo, Brazil. ${ }^{2}$ Department of Maternal and Child Health, School of Public Health, University of Sao Paulo, Sao Paulo, Brazil. ${ }^{3}$ Specialist in Hospital Psychology. Department of Maternal and Child Health, School of Public Health, University of Sao Paulo, Sao Paulo, Brazil. ${ }^{4}$ Department of Maternal and Child Health, School of Public Health, University of Sao Paulo, Sao Paulo, Brazil. ${ }^{5}$ Department of Maternal and Child Health, School of Public Health, University of Sao Paulo. Sao Paulo, Brazil. ${ }^{6}$ Department of Maternal and Child Health, School of Public Health, University of Sao Paulo. Sao Paulo, Brazil.
} 


\section{INTRODUCTION}

The production of care in mental health facilities for children and adolescents is an specific practice due to this particular age group, but also by the type of work that operates in Mental Health Institutions, psychosocial care model. As an example, the service of psychosocial care that assists children and adolescents with intense and persistent psychological suffering who abuse alcohol and other drugs - in this study the so-called Psychosocial Care Center (PCC CAi).

From the criticisms to the question for the treatment referred to insanity and therapeutic addressed for this purpose, the model of psychosocial care is accompanied by other modus of explanation, which resignify the conception of disease and treatment-related practices of insanity. Its theoretical character reaffirms the mode of assistance that puts mental disease between lines, proposing as the focus of treatment, the subject rise on the scene: their subjectivity, their concrete problems of everyday life, their work, family, projects and desires that enable integrality of this subject in the field of Mental Health ${ }^{(1-2)}$.

In the political scenario, the proposed implantation of a network of substitute services related to the psychosocial care for the mental health of children and adolescents - PCC model (children and adolescents for alcohol and drugs), Hospitals-day, Centers, Therapeutic Residencies translate the official discourse of social rehabilitation of patients with mental disorders brought by the Psychiatric Reformation ${ }^{(3-4)}$.

In the context of building a network of care that has PCCi for childhood and adolescence, as coordinators of the network for this age group, the establishment of a national policy assistance to people who use alcohol and drugs, published officially in 2003, is added. This condition unfolds years later in the composition of challenges and the development of networking processes directed toward this age group.

Other facts may be cited as promoters of this discussion:

1) The enactment of the Emergency Plan for Coping Actions on Alcohol and Drugs (EPCAD) which highlights children's and adolescent's care that abuse of alcohol and other drugs(5).

2) The enactment of a new network arrangement, called Network for Psychosocial Care - NPC - for mental health through Ordinance No. 3088/2011, which strengthens the focus of care and creates other opportunities for shelter and protection to this age group with the demand for alcohol and other drugs abuse ${ }^{(6)}$.

3) The enactment of Ordinance 130/2012 of the Brazilian Ministry of Health, which redefines the Psychosocial Care Center of Alcohol and Other Drugs 24 hours (PCC III) as re-authorising network equipment, also expanding the access of children and adolescents through 24 hours day ${ }^{(7)}$.
In this context, the city of Sao Bernardo do Campo metropolitan region of Sao Paulo - takes a unique option in proposing a specific PCC for children and adolescents who abuse alcohol and drugs, called PCC ADi type III.

This study will address the identity of the production of care within a PCC ADi in coping with problems arising from the abuse of alcohol and other drugs in children and adolescents. This care operated in two assisted emblematic cases.

\section{METHOD}

\section{A. Setting}

Child and adolescent Psychosocial Care Center for users of alcohol and drugs - PCC ADi, in the city Sao Bernardo do Campo (SBC) located in Sao Paulo metropolitan mesoregion.

\section{B. Participants}

Professionals with high school completed and higher education workers from the PCC ADi and two users of this health facility.

\section{Procedures}

The study used a research design called "process tracing methodology"(8-11) which brought together four research categories in the discussion around two cases assisted in the PCC ADi.

Thes "process tracing methodology" is described as a study design that can be done prospectively or retrospectively identifying markers (in the case of this study, the therapeutic project assigned to each user of the service) for analyzing a process of care, one process of change or an educational process. According to the authors, the analysis of tracing allows situations to be examined in loco the ways it is materialized in practice, complex work processes, such as health and education, involving a significant degree of autonomy of the professionals ${ }^{(8)}$.

Other authors ${ }^{(9-11)}$ explain it as a method applied to the field of evaluation of health services; research for work processes of a health care team, in the reconstitution of a case, allowing better observation of the act of caring.

The four research categories of the study were constituted from the following arrangement: focus group (registration and collective discussion of two therapeutic projects worked); Form completed by professionals (education, experience, work, expectations, satisfactions and dissatisfactions with the work); interview with two users cared, as well as observation of relevant situations of work processes in the production of care.

The focus group addressed the therapeutic projects of two emblematic cases worked in PCC ADi. The choice of cases was based on the request made to the group of workers that chose a difficult and typical case of the insti- 
tution, and other case which was difficult in the evaluation of the team, which had a satisfactory outcome.

Focus group meetings, important to compose the analysis of care production in the service, were established in four stages, two designated for the discussion of each case chosen.

Data were analyzed from the view of cartography, theoretical framework and modus operandi ${ }^{(12)}$ to capture the intersection between knowledge, doings, technologies and subjectivities ${ }^{(13)}$; allowing us to follow processes and reveal how they operate as working networks ${ }^{(14-15)}$ in the production of children and adolescents mental health care.

\section{Institutional and Ethical aspects}

This study was extracted from a master's dissertation "Work processes in the construction of care: emblematic cases assisted in a Psychosocial Care Center for Alcohol and Drugs for Children and Adolescents (PCC ADi)", approved by the Ethics and Research Committee of the School of Public Health, University of Sao Paulo, under protocol 48303, June 22, 2012.

In the city of SBC, the research project was submitted to and accepted by the Coordinator of Continuing Education in Health and Mental Health Coordinating from municipality secretariat to be conducted at the PCC ADi.

\section{ANALYSIS AND DISCUSSION OF DATA}

The operability of care in PCC, as proposed in the model of psychosocial care depends on an ethos about this production that is built in the composition of stages, segmentarity lines, drain lines and intensities ${ }^{(12)}$, from act of living labor in the institution ${ }^{(16)}$.

The effectiveness of care occurs in the development and reflection on encounters between workers and users, which does not guarantee a priori the production of a "intersectional" care (sic) ${ }^{(16)}$ simply by the fact of being inside a PCC or anywhere in the network of care in mental health.

Thus, the cartography aid in the composition of this care setting by the conjunction of three assumptions in development of the study: the monitoring of practices and processes of production of subjectivities; the composition of a design that accompanies and is at the same time the movements of dynamics transformation and service; capturing the act of forces that occurs in institutional care settings, whereas this production takes place at the level of micro power relations ${ }^{(13,15)}$.

The cartography presented was made from one of three existential territories described by Emerson Merhy, the identity of the health practices field, ie, the scenario which we talk about the care and how operates $\mathrm{it}^{(16)}$.

In these terms, we contextualize the macro scenario of conducting the research in the city of SBC.

\section{The construction of the mental health network in Sao Bernardo do Campo}

The implementation of PCC ADi in SBC was made in 2006 under the pressure from the Public Affairs State Ministry, but had in 2009, a reconfiguration as an authorized Network for Psychosocial Care. It was thought with other health services and protective measures for children and adolescents who were abusing alcohol and drugs in the city. The previous situation were addressed to outpatient and inpatient services that worked in a fragmented way in caring for this age group ${ }^{(17)}$.

The arrangement of EPCAD ensures care for children and adolescents who abuse drugs in the PCC for children and adolescents and PCC AD type III ${ }^{(6-7)}$.

In SBC, the PCC ADi arises from the division of children and adolescents PCC (PCCi), where the demands of alcohol and other drugs abuse were met previously, along with the general demands related to psychological suffering in this age group.

The PCC ADi also emerged initially in the daily running prerogative, and then became 24 hours PCC, adding to their workload the mode described as "night hospitality" and uninterrupted operation.

The temporal and political changes of the service and the fact that most professionals working on the equipment had joined two years before the study, are described by staff as a source of transformations in the dynamics that the PCC assumes in the practices of health. Among the transformations described: periods in which there was greater or lesser workload, and greater or lesser possibility of sharing discussions and questions related to work processes in the production of care within the institution.

The proposition of the PCC ADi is based from the need for specific investment in the area, as well as the assumption of actions in the field of mental health centered on the achievement of therapeutic projects dedicated to the production of life of users in the spaces outside PCC ${ }^{(17)}$. Nevertheless, this network operates within a policy where contradictory practices with regard to assisting user cohabit.

\section{Contradiction of care models in policy to alcohol and drugs use}

The policy of the Brazilian Ministry of Health for assisting users of alcohol and drugs brought historical heritages that composes contradictions in the operation of the model.

In the composition of this model, we can observe closed character institutions, predominantly philanthropic, which grew historically focused on criminalization and prosecution of users of alcohol and drugs, described as "therapeutic communities"(18).

In this regard, there are the care of mental health network of open equipment (PCC AD) who work in the log-
Identity of care in a Psychosocial Care Center for Children and Adolescents who uses drugs

Bastos IT, Junior VS, Oliveira TGP, Delfini PSS, Muylaert CJ, Reis AOA 
ic of harm reduction ${ }^{(19)}$, the psychosocial care model and other designated devices to operate at different levels of complexity and requirements ${ }^{(16,18,19)}$.

In contrast to the composition of this network, there is still a current work of devaluation from the media, call for (re)legalization of the field and attack which is defined as (network) psychosocial care strategy in the treatment effectiveness of these users. It feeds the imaginary of the people on the drug user as sick and dangerous that needs to be hospitalized in a closed institution, primarily aiming at remission and suppression of use, as well as withdrawing the possibility that equipment such as PCC must be resolute in these circumstances ${ }^{(20-23)}$.

These contradictions, however, are present in the daily work, in the complexity of the field of children and adolescents mental health reality.

\section{Competitive models beyond the Unit of Treatment for Chemical Dependency}

Focus groups were the main place for the discussion of various facets of identity that appeared in the work operated in PCC. In one of them, the professionals defined service as "a unit of treatment for chemical dependency". This situation seems to reinforce the centrality of care in the treatment of alcohol and drugs abuse and not the individual who suffers from it.

\begin{abstract}
"So we think that if we are a unit of treatment for chemical dependency someone should answer for sexually transmitted diseases and when we ask for support, in the intensity that one would imagine, it would be important, we cannot find it, it is lost" (Professional A).
\end{abstract}

The competition between the models produced in the care of service users have two ways. One that focuses on the treatment of chemical dependency and not the adolescent suffering from it. Another that recognizes the complexity of the care, which must be operated and claims the partnership of other services in meeting the integrality needs of adolescents. In addition, other issues highlighted were also discussed in the group in parallel:

- statements regarding an overload of work on the part of health workers because of assuming roles and functions that were not within their authority;

- $\quad$ the difficulty of access to family user and the justification that the care of the mother did not relate to the work they should do;

- $\quad$ the desire to get other types of service for users of emblematic cases treated, so that different demands related to drug use were solved by other points in the health network, such as the issue of social vulnerability, poverty and monitoring of physical diseases.

This identity issue on the conception of the treatment focusing on drug use has historical roots in the delay of this area - alcohol and drugs - in the public health agenda and how the proposed policy of integrality of care to users of alcohol and other drugs by the Brazilian Ministry of Health from 2003 to the present ${ }^{(18,19)}$.

\section{Professional profile in the PCC ADi}

The profile of mental health professionals in the PCC $A D i$ follow what has been described as current reality in the composition of health services professionals. Mostly, they had up to two years of work experience in the institution, had no experience with children and adolescents mental health or in the area of alcohol and drugs ${ }^{(23)}$.

When asked about what they considered important in their practice, many responded with discourses near to the Psychosocial/Psychiatric Reform model: possibility of listening and linking, commitment, work with social life, family of the user, valuing citizenship. But, what has been observed is that they have a need for collective spaces discussion in which this discourse is constantly resignified. In addition to this, there is a pressing need for sharing of issues related to daily work that may, in fact, promote the construction of the work processes in which advocates the Psychosocial Care Model.

The PCC ADi was permeated by a daily work which consisted of professionals, their beliefs and diverse experiences, which were not positioned in front of the militancy of the Psychiatric Reform or anti-asylums fight, but found themselves compelled to say it. Moreover, they had neither a long experience of practical political thinking and implementation of the model, nor an institutional clinical work of caring for themselves effectively, ie to compose a network of care for these workers. This work would be translated as an essential tool in everyday service respecting complexity in which the team operates in a responsible exercise of clarification of specific clinical events ${ }^{(23)}$.

The care in psychosocial care center is done by composing the network of care, care for themselves and care for each other.

\section{The composition of the network (team) and contractuality outside PCC}

A fact highlighted from a professional statement in the focus group is the difficulty that they report to the joint work with the network when they define as "supermom", taking on issues that should be of other services.

"we used to make jokes that PCC was a "supermom", then we wanted to centralize everything, but the more we stay in this position, I do not know if the other will conduct the service (...) this is an absurd change of thinking" (Professional B)

In this case, PCC is a point on the network that cannot operate in the psychosocial logic, or even that are not investing in power of contractuality that must have together with other services in the territory. 
It is believed that the PCC produces care while coordinator of the network of services in mental health and in the psychosocial logic. Operating in the complexity of this logic and related to the conditions that PCC has to articulate, to produce shared work on a new way of looking at the network and in the production of increasingly singular encounters between the equipment and the target subjects of care $^{(24)}$.

"Network is therefore a notion that necessarily implies the dimension of otherness, having or not having other services, beyond that which occurs in certain act of care"(24 p.51).

The notion of network design is used here, according to Deleuze and Guattari, who defines it as rhizome, as a centered system that configures and desconfigures from movements, flows, connections and alliances between different actors ${ }^{(12,25)}$; while a "tension field of heterogeneous forces, thus combining the differences in their multiplicity"(25 p.33).

The idea of composing a network while a centered system, being fed by several points, raises the question of identity addressed, as this happens differently in the concept that professionals have about their place in the mental health services, as well as their articulation with other resources.

It is worth noting that the service identity also constitutes the exercise of successive discussions, pairings, articulations and it was clear from the complaint and reflection arising from the professional discourse at focus group sessions and observation in the institutions.

In this regard, it is known that mental health is part of a municipality with devices producing a network, such as: the work of supporters (people allocated in the territories that make relationship between the services), management collegiate which team discusses cases involving intersectional actions and other continuing education actions that proposes to support and build network where it is necessary. Therefore, there is a need to the team negotiating and coordinating with various production spaces of collective reflection.

Continuously, the processes of discussion and clinical-institutional analysis must favor the construction of a set of ideas about care and a psychosocial identity for the service. This reflection is shown small in the statements of professionals about reflection processes in the production of care.

Another difficulty observed and reported in the construction of collective ideas about care and argued in other studies ${ }^{(26-28)}$ was the difference between the activities developed, particularly by nursing staff and other PCC professionals. The nursing staff was concerned with giving medication, organization of the routine, use of telephone and keys, referring testing and surveillance body-to-body at the gates and other dependencies of the institution, in- cluding the expectation that they could escape. This fact complicated the ownership and team integration with work processes in psychosocial model.

In these terms, it can be stated that the psychosocial model is presented as something that is not ready and cannot simply be applied via interdiction, a fact that relates the history of the service, established from a determination of the Ministry of Public Affairs.

The model, as well as the production of care that happens in a collective manner, creates as we move forward to take the effects produced by the processes of subjectivation of our decisions in everyday life. Thus, the cases assisted by staff may be a problematization of devices and reflection of a care located on the uniqueness of the service users.

\section{CONCLUSION}

The contribution of the study is the way of presenting the daily life of a PCC as something that is still being built. Then, it is understood that the model of psychosocial care within services is going through a construction that is continuous and diverse, always needing a feedback and the collective resignificance.

The use of the research design called "process tracing methodology" allowed reflection in the production of care in cases from various perspectives - observations, charts, statements of users on their service, as well as the professionals' statements in a collective analysis. This allowed the construction of a view that was reanalyzed and rebuilt at various moments from recovery information. It provided opportunities for reflection that competes to the complexity of the research field itself.

The study shows markedly the competition and tensions between the knowledge, values and work processes built in practice between professionals, family members and users in each contractuality within the service. In this everyday, life a powerful and necessary point of departure for thinking about the scenario and production of care which the institution operates.

This also brings up the discussion on the management of care before a super specialized situation, children and adolescents who use drugs. In addition, how we should not operate in a fragmented way, discussing what types of devices may potentialize reflective processes and caregivers around the mental health work. Furthermore, one must question the composition of scenarios of care, while places that fragments parts of the human suffering, such as alcohol and drugs abuse, violence, social vulnerability, among others. Thus, enhancing local solutions and/or options that assist the person in their integrality and not just their problem.

The cartography of the territory of institutional identity, or the identity of care, externalised identity issues as
Identity of care in a Psychosocial Care Center for Children and Adolescents who uses drugs

Bastos IT, Junior VS, Oliveira TGP, Delfini PSS, Muylaert CJ, Reis AOA 
described and experienced by professionals composing a modus operandi of the team and from mental health care.

Understanding the network as a rhizome, centered with multiple entries, one can also think that collective workspaces, reflection and re-contratuality should always be reconsidered as important institutional clinical devices in the construction of mental health care.

\section{REFERENCES}

1. Costa-Rosa A, Luzio ACA, Yasui S.. Atenção psicossocial: rumo a um novo paradigma na saúde mental coletiva. In: Amarante $\mathrm{P}$, organizadores. Archivos de saúde mental e atenção psicossocial. Rio de Janeiro: NAU Editora; 2003.

2. Reis AOA. Os Centros de Atenção Psicossocial Infantojuvenis no Estado de São Paulo. [Tese de livre docência]. São Paulo: SP. Faculdade de Saúde Pública da Universidade de São Paulo; 2010.

3. Brasil. Ministério da Saúde (BR). Secretaria de Atenção à Saúde. Departamento de Ações Programáticas Estratégicas. Saúde Mental no SUS. Os Centros de Atenção psicossocial. Ministério da Saúde. Secretaria de Atenção a Saúde. Departamento de Ações Programáticas Estratégicas; 2004.

4. Lauridsen-Ribeiro E, Tanaka OY. Organização de serviços no Sistema Único de Saúde para o cuidado de crianças e adolescentes com problemas de saúde mental. In: Lauridsen-Ribeiro $E$, e Tanaka, organizadores. Atenção em saúde mental para crianças e adolescentes no SUS. São Paulo: Hucitec; 2010. p.147-169.

5. Brasil. Ministério da Saúde. Portaria n 1190 de 04 de junho de 2009. Institui o Plano Emergencial de Ampliação do Acesso ao Tratamento e Prevenção em Álcool e outras Drogas no Sistema Único de Saúde - SUS (PEAD 2009-2010) e define suas diretrizes gerais, ações e metas[Internet]. 2009 Jun 04 [acesso em 2014 set 09]. Disponível em: http://bvsms.saude.gov.br/ bvs/saudelegis/gm/2009/prt1190_04_06_2009.html

6. Brasil. Ministério da Saúde. Gabinete do Ministro. Portaria no 3.088, de 23 de dezembro de 2011. Institui a Rede de Atenção Psicossocial para pessoas com sofrimento ou transtorno mental e com necessidades decorrentes do uso de crack, álcool e outras drogas, no âmbito do Sistema Único de Saúde [Intenet] 2011 dez 23 [acesso em 2014 set 09]. Disponível em: http:// www.brasilsus.com.br/legislacoes/gm/111276-3088.html.

7. Brasil. Ministério da Saúde. Gabinete do Ministro. Portaria no 130, de 26 de janeiro de 2012. Redefine o Centro de Atenção Psicossocial de Álcool e outras Drogas 24 h (CAPS AD III) e os respectivos incentivos financeiros [Internet]. 2012 jan 26 [acesso em 2014 ago 23]. Disponível em: http://bvsms.saude. gov.br/bvs/saudelegis/gm/2012/prt0130_26_01_2012.htm.

8. Feuerwerker LCM, Merhy EE. Como temos armado e efetivado nossos estudos, que fundamentalmente investigam políticas e práticas sociais de gestão e de saúde? In: Mattos RA, Baptista TWF, organizadores. Caminhos para análise das políticas de saúde; 2011. p. 290-305.
9. Carvalho LC. A disputa de planos de cuidado na atenção domiciliar [Dissertação de mestrado]. Rio de Janeiro, RJ: Universidade Federal do Rio de Janeiro Faculdade de Medicina; 2009.

10. Horta NC, Sena RR, Silva MEO, Tavares TS, Caldeira IM. A pratica de grupos como ação de promoção de sáude na estratégia saúde da familia. Revista APS. 2009; 12(3):293-301.

11. Freitas P. A percepção dos usuários sobre a oferta de programas de promoção da saúde e prevenção de doenças no sistema suplementar de saúde no Estado do Espírito Santo [Dissertação de mestrado]. Vitória, Espirito Santo: Universidade Federal do Espirito Santo; 2009.

12. Deleuze G, Guatarri F. Mil platôs - capitalismo e esquizofrenia [AG Neto, CP Costa, trans]. Rio de Janeiro: Ed. 34; 1995.

13. Feuerwerker LCM. Micropolítica e saúde: produção do cuidado, gestão e formação [Tese de livre docência]. São Paulo: SP: Faculdade de Saúde Pública da Universidade de São Paulo; 2012.

14. Merhy EE, Franco TB. Por uma composição técnica do trabalho centrada nas tecnologias leves e no campo relacional. Saúde em Debate, ano XXVII. 2003; 27(65).

15. Barros LP, Kastrup V. Cartografar é acompanhar processos. In: Passos E, Kastrup V, Escócia L, organizadores. Pistas do Método cartográfico: pesquisa-intervenção e produção de subjetividade. Porto Alegre: Sulina; 2009.

16. Merhy EE. Saúde: cartografia do trabalho vivo. São Paulo: Hucitec; 2002

17. Furtado LAC, Zaparoli C, Chioro A, Robortela S. Política de atenção e prevenção às pessoas em situação de uso abusivo de álcool e outras drogas no município de São Bernardo do Campo - SP. In: Lancetti A, Chioro A, Vargas B, Zaparoli C, Petuco DRS, Castilho EWV, Merhy EE, Furtado LAC, Oliveira MV, Robortela S, organizadores. Drogas e cidadania em debate.1 1 a edição. Grupo de Trabalho de álcool e outras drogas. Brasília, DF:Conselho Federal de Psicologia. Conselho Regional de Psicologia; 2012. p. 53-61.

18. Machado AR, Miranda PSC. Fragmentos da história da atenção a usuários de álcool e outras drogas no Brasil: da justiça à saúde pública. História, Ciências, Saúde - Manguinhos. Rio de Janeiro, RJ. 2007; 14(3): 801-821. 
19. Brasil. Ministério da Saúde. Secretaria Executiva. Coordenação Nacional de DST e AIDS. A Política do Ministério da Saúde para atenção integral a usuários de álcool e outras drogas. Ministério da Saúde, Secretaria Executiva, Coordenação Nacional de DST e Aids [Internet]. Brasília: Ministério da Saúde. 2003 [acesso em 2014 set 03]. Disponível em: http://bvsms.saude.gov.br/bvs/publicacoes/pns_alcool_drogas.pdf

20. Romanini M, Roso A. Mídia e crack: promovendo saúde ou reforçando relações de dominação? Psicologia Ciência e Profissão. 2012; 32(1): 3282-97.

21. Lancetti A. Clinica peripatética. São Paulo: HUCITEC; 2012.

22. Castilho EWV, A eficácia invertida da internação compulsória. In: Lancetti A, Chioro A, Vargas B, Zaparoli C, Petuco DRS, Castilho EWV, E. E. Merhy, Furtado LAC, Oliveira MV, Robortela $\mathrm{S}$, organizadores. Drogas e cidadania em debate. 1a edição. Grupo de Trabalho de álcool e outras drogas. Brasília - DF: Conselho Federal de Psicologia. Conselho Regional de Psicologia; 2012.p.35-37.

23. Marazina IV. A saúde mental pública na América Latina. Estudo comparativo dos sistemas de saúde mental de Argentina e Brasil [Tese de Doutorado]. São Paulo, SP: Universidade de São Paulo. Faculdade de Saúde Pública; 2011.

24. Elia L, A rede de atenção na saúde mental: a articulação entre CAPS e ambulatórios. In: Ministério da Saúde, organizadores. Secretaria de Atenção a Saúde e Departamento de Ações Programáticas e Estratégicas. Caminhos para uma política de saúde mental infanto-juvenil. Série B. Textos básicos em saúde. Brasília: Editora do Ministério da Saúde; 2005. p.49-61.
25. Ferreira FT. Rizoma: um método para as redes? Liinc em Revista. Rio de Janeiro [Internet]. 2008 [acesso em 2014 março 23];4(1):28-40. Disponível em: <http://revista.ibict.br/liinc/ index.php/liinc/article/viewFile/251/142>

26. Filizola CLA, Millioni DB, Pavarini SCl. A vivência dos trabaIhadores de um CAPS diante da nova organização do trabaIho em equipe. Revista Eletrônica de Enfermagem [Internet]. 2008 [acesso em 2014 set 03];10(2):491-503. Disponível em:http://www.fen.ufg.br/revista/v10/n2/v10n2a20.htm.

27. Dias $C B$, Aranha e Silva AL. O perfil e a ação profissional da(o) enfermeira(o) no Centro de Atenção Psicossocial. Revista da Escola de Enfermagem da USP, São Paulo [Internet]. 2010 [acesso em 2014 junho 23; 44(2):469-475. Disponível em: http://www.scielo.br/pdf/reeusp/v44n2/32.

28. Rocha RM. O enfermeiro na equipe interdisciplinar do Centro de Atenção Psicossocial e as possibilidades de cuidar. Texto contexto - Enfermagem. Florianópolis [Internet]. 2005 [acesso em 2014 set 02]; 14(3):350-357. Disponível em: http://www.scielo.br/pdf/tce/v14n3/v14n3a05.pdf.Nightingale F. Notes on nursing. What it is, and what it is not. New-York: D. Appleton and Company; 1860.

29. Rodrigues A. A dimensão estética do cuidar em Enfermagem. Revista referência.2002; supl.

30. Madureira V. Os saberes da enfermagem. Rev Bras Enferm. 2004; 57(3): 357-360.

31. Hammerschmidt K, Borghi A, Lenardi M. Ética e estética na promoção do cuidado gerontológico em enfermagem. Texto Contexto Enfermagem. 2006; 15 (Esp): 114-124. 